\title{
Effects of Walking in a Forest on Young Women
}

\author{
Chorong Song ${ }^{1,+}$ (D), Harumi Ikei ${ }^{1,2,+}$ (D), Takahide Kagawa ${ }^{2}$ (1) and Yoshifumi Miyazaki ${ }^{1, *}$ (1) \\ 1 Center for Environment, Health and Field Sciences, Chiba University, 6-2-1 Kashiwa-no-ha, \\ Kashiwa, Chiba 277-0882, Japan; crsong1028@chiba-u.jp (C.S.); ikei0224@ffpri.affrc.go.jp (H.I.) \\ 2 Forestry and Forest Products Research Institute,1 Matsunosato, Tsukuba, Ibaraki 305-8687, Japan; \\ kagawa@ffpri.affrc.go.jp \\ * Correspondence: ymiyazaki@faculty.chiba-u.jp; Tel.: +81-4-7137-8113; Fax: +81-20-4666-0398 \\ + These authors contributed equally to this work.
}

Received: 3 December 2018; Accepted: 11 January 2019; Published: 15 January 2019

\begin{abstract}
The effects of forest activities on health promotion have received increasing attention. The aim of this study was to evaluate the physiological and psychological effects of brief walks in forests on young women. The experiments were conducted in 6 forests (test) and 6 city areas (control). Overall, 12 participants in each area (60 participants in total, mean age: $21.0 \pm 1.3$ years) were instructed to walk in a forest and a city area for approximately $15 \mathrm{~min}$; simultaneously, their heart rate variability, heart rate, blood pressure, and pulse rate were measured to quantify their physiological responses to walking. The modified semantic differential method, Profile of Mood States (POMS), and the State-Trait Anxiety Inventory (STAI) were used to determine their psychological responses. Walking in a forest was associated with significantly higher parasympathetic nervous activity and lower sympathetic nervous activity and heart rate. In addition, scores for the comfortable, relaxed, and natural parameters and vigor subscale of POMS were significantly higher, whereas scores for negative feelings, such as tension-anxiety, depression-dejection, anger-hostility, fatigue, and confusion, were significantly lower, as were the total mood disturbance of POMS and the anxiety dimension of the STAI. The subjective evaluations were generally in accordance with the physiological responses. A brief walk in a forest resulted in physiological and psychological relaxation effects in young women.
\end{abstract}

Keywords: shinrin-yoku; forest therapy; brief walks; females; heart rate variability; blood pressure; pulse rate; semantic differential method; Profile of Mood State; State-Trait Anxiety Inventory

\section{Introduction}

People are exposed to many stressors in daily life; in response, they try to find effective methods to cope with stress and to relax. One result of this has been the increased focus on using forest environments as places for promoting health through taking in the forest atmosphere, an approach known as "shinrin-yoku" or "forest bathing" [1,2]. It has been suggested that forest bathing, which is based on proven effects of a forest environment such as inducing relaxation, can improve the health of the body and mind. The accumulation of data has resulted in the concept of "forest therapy"; this refers to evidence-based forest bathing with the aim of achieving a preventive medical effect by inducing physiological relaxation and immune system recovery [3].

Numerous studies have demonstrated the effects of forest environments in mitigating stress states and inducing physiological relaxation [4-13]. Studies on healthy young men have demonstrated that time spent in a forest environment, such as walking through a forest and/or viewing the scenery, can reduce levels of salivary cortisol, a stress hormone [4-11], blood pressure [5,8,9,12], and pulse rate $[5,7,8,10,12]$, as well as increase parasympathetic nervous activity, which is enhanced in relaxing situations [5,7,9-13]. In addition, sympathetic nervous activity, which increases in stressful situations, is suppressed [5,9-13], and there is a decrease in the cerebral blood flow in the prefrontal cortex [6]. 
A forest therapy trip has also been shown to increase natural killer (NK) cell activity and improve immunity, with these effects lasting for approximately one month [14,15].

In addition to many studies targeting healthy young men, studies including large sample sizes $[9,16]$ and population-based studies, have also been reported [17-19]. In a study involving 420 participants, Park et al. [16] demonstrated that forest therapy mitigated stress and led to physiological relaxation, as evidenced by the index of heart rate variability (HRV), blood pressure, pulse rate, and salivary cortisol concentration. They performed the experiments at 35 locations throughout Japan including 12 participants in each area and summarized the data. Kobayashi et al. evaluated the characteristics of HRV distribution for 625 participants who viewed forest scenery [17] and 485 participants who walked in forests [19] as well as the characteristics of salivary cortisol concentration for 348 participants who viewed forest scenery [18] by collecting data from 12 participants in each area. In addition, recent studies involving elderly individuals and adults at risk of stress- and lifestyle-related diseases, such as high blood pressure, diabetes, and depression, have demonstrated positive physiological effects resulting from various activities in forests [20-28].

However, most studies involving forest therapy experiments have reported the various effects on male subjects [4-19,24,25,28], with few reports focusing on female subjects [23,29-31]. In a study of elderly women, Lee and Lee [23] reported that walking in a forest for $1 \mathrm{~h}$ improved arterial stiffness and pulmonary function. Ochiai et al. [29] investigated the effects of a one-day forest therapy program on middle-aged women and reported that the pulse rate and salivary cortisol levels decreased significantly following the program. Li et al. [30] examined the effects of a three-day, two-night trip to the forest on young women and reported that NK cell activity increased and remained at a raised level for more than 7 days after the trip. Kim et al. [31] also reported enhanced NK cell activation; their study involved patients with breast cancer who underwent daily forest therapy for 14 days while living in an accommodation in the forest. The increased NK cell activity led to the production of two anticancer molecules [31]. However, these studies were limited by their small sample sizes. Further data are required.

The aim of the present study was to clarify the physiological and psychological effects on young women of brief walks through forests.

\section{Materials and Methods}

\subsection{Participants}

Between 2014 and 2017, we conducted experiments in six forests and six city areas in Japan. In each region, we selected safe, well-maintained forest areas, as well as city areas that were located either downtown or near a Japan Railway station. Twelve Japanese female university students participated in each experiment (a total of $\mathrm{N}=72$ participants). None of the participants reported a history of physical or psychiatric disorders. Of the 72 participants, data from 60 participants (mean age, $21.0 \pm 1.3$ years) were analyzed, because of errors in the data collection (Table 1). During the study period, the participants were prohibited from consuming alcohol and tobacco, and caffeine consumption was controlled. The study was approved by the Ethics Committee of the Center for Environment, Health, and Field Sciences, Chiba University, Japan (project identification code number: 5). Before starting the experiments, we explained the aims and procedures of the study to the participants and obtained their written informed consent.

Table 1. Participant characteristics $(\mathrm{N}=60)$.

\begin{tabular}{cc}
\hline Parameter & Mean \pm Standard Deviation \\
\hline Age (years) & $21.0 \pm 1.3$ \\
Height $(\mathrm{cm})$ & $158.4 \pm 5.3$ \\
Weight $(\mathrm{kg})$ & $50.7 \pm 6.8$ \\
$\mathrm{BMI}^{1}\left(\mathrm{~kg} / \mathrm{m}^{2}\right)$ & $20.2 \pm 2.3$ \\
\hline \multicolumn{2}{c}{${ }^{1}$ BMI: body mass index. }
\end{tabular}




\subsection{Experimental Design}

To eliminate order effects, the 12 participants were randomly divided into two groups of six. One group performed the experiment in the forest area, and the other performed the same experiment in the urban area. On the following day, the groups switched field sites. The details regarding the experiment sites in the forest have been summarized in Table 2.

On arrival in the forest or city area, the participants waited in a waiting room and were taken one at a time to the experimental site. After resting in a chair for $5 \mathrm{~min}$ at the site, the participant's blood pressure and pulse rate were measured to obtain the values before walking. The participant then walked along a given course in the experimental area for approximately $15 \mathrm{~min}$ at her normal walking pace (Figure 1). The walking course in each area was approximately $1 \mathrm{~km}$, and the distances between the forest and city areas were almost same in each area. During the walking period, her HRV and heart rate were measured continuously. After completing the walk, the participant rested for $5 \mathrm{~min}$ in a chair and her blood pressure and pulse rate were again measured. After completing all the physiological measurements, the participant underwent the subjective assessment and returned to the waiting room.

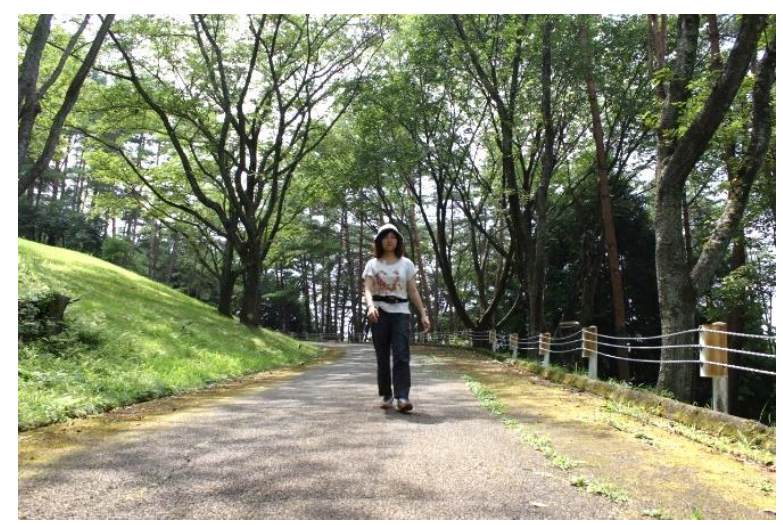

(a)

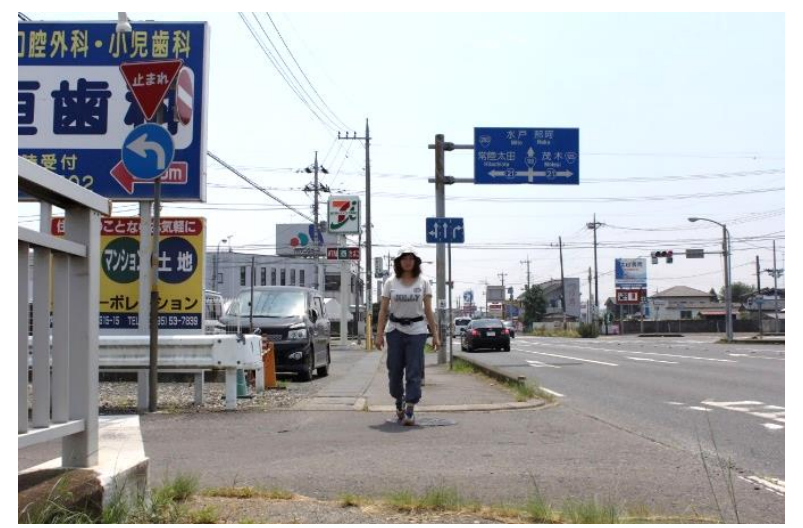

(b)

Figure 1. Walking through forest (a) and city (b) areas.

\subsection{Physiological Measurements}

The physiological measurements made in this study were of HRV, heart rate, blood pressure, and pulse rate. HRV was analyzed for the periods between consecutive $R$ waves ( $R-R$ intervals), measured by a portable electrocardiograph (Activtracer AC-301A, GMS, Tokyo, Japan) [32,33]. This device used a three-lead electrocardiogram (Lead II) to obtain the necessary measurements. Power levels for the high-frequency ( $\mathrm{HF}, 0.15-0.40 \mathrm{~Hz}$ ) and low-frequency (LF, 0.04-0.15 Hz) components of HRV were calculated using the maximum entropy method (MemCalc/Win, GMS, Tokyo, Japan) [34,35]. The HF power is considered to be an indicator of parasympathetic nervous activity and the LF/HF power ratio an indicator of sympathetic nervous activity [36,37]. To normalize the HRV parameters across the participants, the HF power and LF/HF ratio values were transformed to their natural logarithmic values $(\ln (\mathrm{HF})$ and $\ln (\mathrm{LF} / \mathrm{HF})$, respectively) [38]. The overall mean walking period was used in the analysis.

Systolic blood pressure (SBP), diastolic blood pressure (DBP), and pulse rate in the right upper arm were measured by an oscillometric method using a digital blood pressure monitor (HEM1020, Omron, Kyoto, Japan). Each was measured twice; if the two values of SBP differed by $>10 \mathrm{mmHg}$ and/or the DBP values differed by $>6 \mathrm{mmHg}$, an additional measurement was taken. The mean of the two or three measurements was used in the analysis. 
Table 2. The details regarding the experiment sites in the forest.

\begin{tabular}{|c|c|c|c|c|c|c|}
\hline & 1 & 2 & 3 & 4 & 5 & 6 \\
\hline Experimental location & $\begin{array}{l}\text { Iwate Town, Iwate } \\
\text { Prefecture }\end{array}$ & $\begin{array}{l}\text { Motosu City, Gifu } \\
\text { Prefecture }\end{array}$ & $\begin{array}{l}\text { Shiso City, Hyogo } \\
\text { Prefecture }\end{array}$ & $\begin{array}{l}\text { Daigo Town, Ibaraki } \\
\text { Prefecture }\end{array}$ & $\begin{array}{l}\text { Hakone Town, Kanagawa } \\
\text { Prefecture }\end{array}$ & $\begin{array}{l}\text { Oi Town, Kanagawa } \\
\text { Prefecture }\end{array}$ \\
\hline Experimental period & 5-6 August 2014 & 12-13 August 2014 & 21-22 August 2014 & 6-7 August 2015 & 2-3 September 2015 & 5-6 September 2017 \\
\hline Forest physiognomy & $\begin{array}{l}\text { Secondary forest (Red } \\
\text { pine \& Oak) and } \\
\text { artificial forest (Larch) }\end{array}$ & $\begin{array}{l}\text { Secondary forest (Oak } \\
\& \text { Cherry) }\end{array}$ & $\begin{array}{l}\text { Secondary forest (Oak } \\
\text { \& Maple) }\end{array}$ & $\begin{array}{l}\text { Secondary forest (Red } \\
\text { pine \& Oak) }\end{array}$ & $\begin{array}{l}\text { Secondary forest (Red } \\
\text { pine \& Oak) }\end{array}$ & $\begin{array}{l}\text { Secondary forest (Oak) } \\
\text { and artificial planting } \\
\text { (Ginkgo) }\end{array}$ \\
\hline Weather & $\begin{array}{l}\text { 1st day: sunny } \\
\text { 2nd day: sunny }\end{array}$ & $\begin{array}{l}\text { 1st day: sunny } \\
\text { 2nd day: sunny }\end{array}$ & $\begin{array}{l}\text { 1st day: sunny } \\
\text { 2nd day: rainy }\end{array}$ & $\begin{array}{l}\text { 1st day: sunny } \\
\text { 2nd day: sunny }\end{array}$ & $\begin{array}{l}\text { 1st day: rainy } \\
\text { 2nd day: cloudy }\end{array}$ & $\begin{array}{l}\text { 1st day: sunny } \\
\text { 2nd day: cloudy }\end{array}$ \\
\hline Temperature $\left({ }^{\circ} \mathrm{C}\right)\left(\right.$ mean $\left.\pm \mathrm{SD}^{1}\right)$ & $\begin{array}{l}\text { Forest: } 26.6 \pm 0.5 \\
\text { City: } 28.1 \pm 0.6\end{array}$ & $\begin{array}{l}\text { Forest: } 28.3 \pm 1.0 \\
\text { City: } 29.1 \pm 0.8\end{array}$ & $\begin{array}{l}\text { Forest: } 25.3 \pm 1.4 \\
\text { City: } 29.9 \pm 1.2\end{array}$ & $\begin{array}{l}\text { Forest: } 33.3 \pm 0.8 \\
\text { City: } 35.9 \pm 0.8\end{array}$ & $\begin{array}{l}\text { Forest: } 26.3 \pm 0.5 \\
\text { City: } 27.7 \pm 0.3\end{array}$ & $\begin{array}{l}\text { Forest: } 24.8 \pm 0.4 \\
\text { City: } 27.4 \pm 0.6\end{array}$ \\
\hline Humidity (\%) (mean \pm SD) & $\begin{array}{l}\text { Forest: } 83.5 \pm 2.3 \\
\text { City: } 74.9 \pm 2.9\end{array}$ & $\begin{array}{l}\text { Forest: } 75.5 \pm 5.3 \\
\text { City: } 68.6 \pm 3.3\end{array}$ & $\begin{array}{l}\text { Forest: } 83.0 \pm 5.0 \\
\text { City: } 63.6 \pm 5.2\end{array}$ & $\begin{array}{l}\text { Forest: } 54.2 \pm 3.1 \\
\text { City: } 50.2 \pm 2.2\end{array}$ & $\begin{array}{l}\text { Forest: } 75.5 \pm 1.3 \\
\text { City: } 72.4 \pm 2.8\end{array}$ & $\begin{array}{l}\text { Forest: } 77.9 \pm 1.9 \\
\text { City: } 62.7 \pm 2.2\end{array}$ \\
\hline Illuminance (lx) (mean) & $\begin{array}{l}\text { Forest: } 2420 \\
\text { City: } 7280\end{array}$ & $\begin{array}{l}\text { Forest: } 7390 \\
\text { City: } 7630\end{array}$ & $\begin{array}{l}\text { Forest: } 5670 \\
\text { City: } 10,300\end{array}$ & $\begin{array}{l}\text { Forest: } 1040 \\
\text { City: } 9530\end{array}$ & $\begin{array}{l}\text { Forest: } 1110 \\
\text { City: } 3760\end{array}$ & $\begin{array}{l}\text { Forest: } 1920 \\
\text { City: } 4980\end{array}$ \\
\hline
\end{tabular}




\subsection{Psychological Measurements}

The psychological evaluations used the modified semantic differential (SD) method, the Profile of Mood State (POMS) and State-Trait Anxiety Inventory (STAI) questionnaires. The SD method obtains a subjective assessment from the participant through a questionnaire comprising pairs of opposing adjectives, each evaluated on a 13-point scale [39]. Three pairs of adjectives were assessed: "comfortable-uncomfortable", "relaxed-awakening", and "natural-artificial".

The POMS is a well-established measure of psychological distress derived from factor analysis, and its high levels of reliability and validity have been documented [40,41]. It simultaneously evaluates six moods: tension and anxiety (T-A), depression and dejection (D), anger and hostility (A-H), fatigue $(F)$, confusion $(C)$, and vigor $(V)$. The total mood disturbance score was calculated from the formula $[(T-A)+(D)+(A-H)+(F)+(C)-(V)][40]$. The total mood disturbance score is understandable from a clinical perspective and intercorrelations among the six primary POMS factors suggest that it is highly reliable [41]. In this study, we used the Japanese version of the POMS in a short form with 30 questions [42] to reduce the burden on the participants.

The STAI form X was used to assess the participants' state anxiety level. STAI is a self-reported tool that measures the current presence and severity of symptoms of anxiety and a generalized propensity to be anxious [43]. State anxiety is a measure of the current state of anxiety (how the respondent feels "right now"), as assessed by 20 questions [44].

\subsection{Data Analysis}

The analysis included the HRV and heart rate data of 52 participants and the blood pressure and pulse rate data of 46 participants, because of errors in the data collection. The statistical analyses were performed using SPSS version 20.0 (IBM Corp., Armonk, NY, USA). Paired t-tests were used to compare physiological responses between the forest and city areas. The Wilcoxon signed-rank test was used to compare the psychological responses. For all the analyses, a $p$-value $<0.05$ was considered statistically significant. One-sided tests were used because it was hypothesized that the participants would be physiologically and psychologically relaxed by walking in forests.

\section{Results}

There was no significant difference between the two environments in the participants' walking speed (forest: $3.63 \pm 0.62 \mathrm{~km} / \mathrm{h}$; city: $3.73 \pm 0.74 \mathrm{~km} / \mathrm{h} ; p>0.05$ ). However, the participants exhibited statistically significant differences in their physiological and psychological responses to the walks in the forest and city areas. The mean value of $\ln (\mathrm{HF})$, an indicator of parasympathetic nervous activity, averaged over the entire walking period, was significantly higher for forest walking than for city walking (forest: $4.31 \pm 0.12 \mathrm{lnms}^{2}$; city: $3.52 \pm 0.14 \mathrm{lnms}^{2} ; p<0.01$; Figure 2). There was also a significant difference in the original, non-logarithmic HF values (forest: $105.12 \pm 14.01 \mathrm{~ms}^{2}$; city: $57.11 \pm 10.36 \mathrm{~ms}^{2}$; $p<0.01)$. In contrast, $\ln (\mathrm{LF} / \mathrm{HF})$, an indicator of sympathetic nervous activity, was significantly lower during forest walking than during city walking (forest: $1.58 \pm 0.09$; city: $1.88 \pm 0.10 ; p<0.01$; Figure 3). There was also a significant difference in the LF/HF ratio values before taking the logarithm (forest: $6.10 \pm 0.67$; city: $8.19 \pm 0.76 ; p<0.01$ ). In addition, the mean heart rate was significantly lower during forest walking than during city walking (forest: $87.0 \pm 1.1 \mathrm{bpm}$; city: $95.6 \pm 1.4 \mathrm{bpm} ; p<0.01$; Figure 4). 


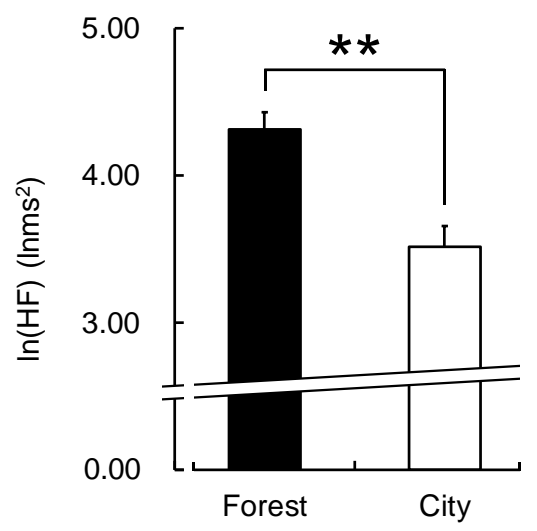

Figure 2. The natural logarithm of the high-frequency power component of heart rate variability while walking in forest and city areas. Data are shown as means \pm standard error $(n=52) .{ }^{* *} p<0.01$, paired $t$-test (one-sided).

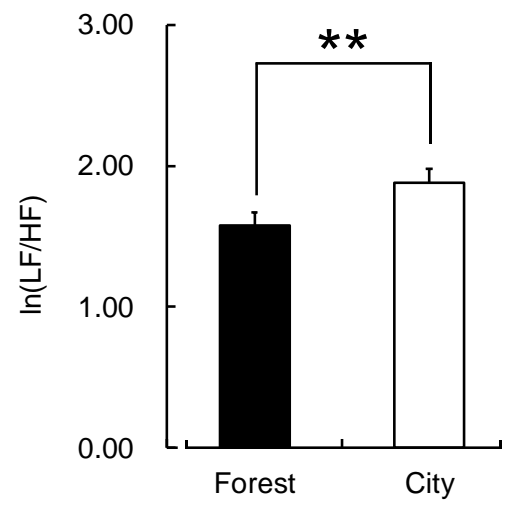

Figure 3. The natural logarithm of the heart rate variability low frequency/high frequency ratio while walking in forest and city areas. Data are presented as means \pm standard error $(\mathrm{n}=52) .{ }^{* *} p<0.01$, paired $t$-test (one-sided).

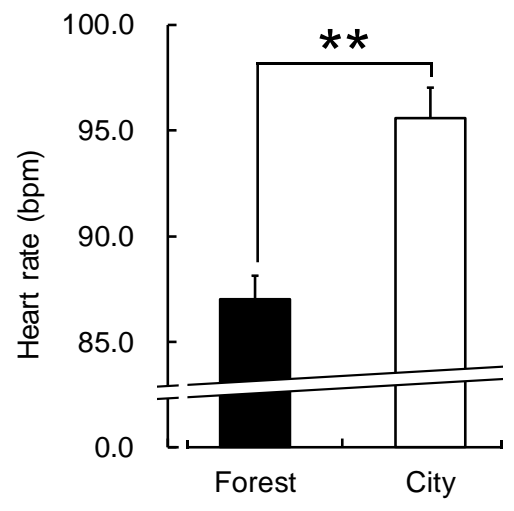

Figure 4. Heart rate during walking in forest and city areas. Data are shown as means \pm standard error ( $\mathrm{n}=52) .{ }^{* *} p<0.01$, paired $t$-test (one-sided).

There were no significant differences in SBP or DBP between the forest and city areas (SBP after the forest walk: $97.3 \pm 1.2 \mathrm{mmHg}$; SBP after the city walk: $97.5 \pm 1.2 \mathrm{mmHg} ; p>0.05$; DBP after the forest walk: $59.8 \pm 0.9 \mathrm{mmHg}$; DBP after the city walk: $59.2 \pm 1.1 \mathrm{mmHg} ; p>0.05)$. There were no significant differences in the blood pressure values before and after walking in either area. The pulse rate after walking differed significantly between the forest and city areas (forest: $69.3 \pm 1.2 \mathrm{bpm}$; city: $71.9 \pm 1.3 \mathrm{bpm} ; p<0.05$ ), although there was no significant difference before walking (forest: $67.9 \pm 1.1 \mathrm{bpm}$, city: $69.4 \pm 1.3 \mathrm{bpm}$; $p>0.05)$. The pulse rate increased between before and after walking in both areas. 
Significant differences between the forest and city experiments were observed for all the psychological measures. Figure 5 shows the results of the modified SD method. The subjective evaluations indicated that the participants felt significantly more "comfortable," "relaxed," and "natural" when walking in forests than when walking in city areas (all $p<0.01)$.

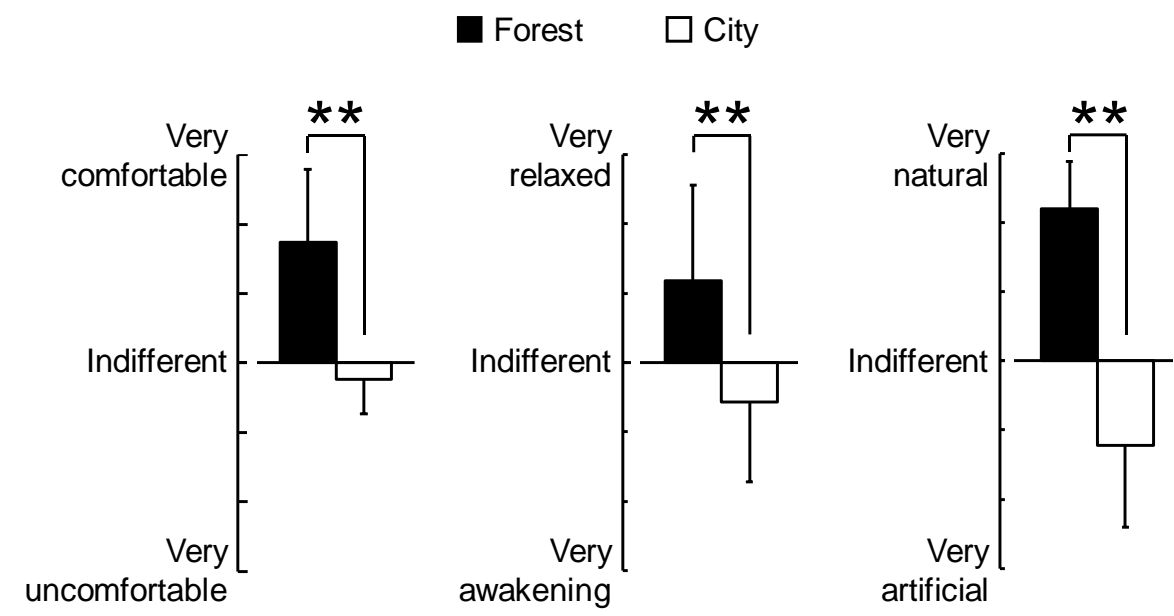

Figure 5. Subjective feelings after walking in forest and city areas, assessed using the modified semantic differential method. Data are shown as means \pm standard deviation $(n=60) .{ }^{* *} p<0.01$, Wilcoxon signed-rank test (one-sided).

Significant differences between the forest and city areas were observed for all the POMS subscales rated after walking and for the total mood disturbance score (Figure 6). The subscale scores for the forest and city areas were as follows: tension and anxiety subscale, $1.1 \pm 1.8$ vs. $2.9 \pm 2.8$; depression and dejection, $0.4 \pm 0.8$ vs. $0.6 \pm 1.4$; anger and hostility $0.1 \pm 0.3$ vs. $0.5 \pm 1.1$; fatigue, $0.6 \pm 1.1$ vs. $2.2 \pm 2.5$; and confusion, $3.5 \pm 1.0$ vs. $4.0 \pm 1.2$. All these negative mood state scores were significantly lower after walking in the forest than after walking in the city (all $p<0.01$, except for depression and dejection, $p<0.05)$. In contrast, the vigor subscale score after walking in the forest was $5.6 \pm 3.5$, which was significantly higher than $2.5 \pm 2.8$ after walking in a city area $(p<0.01)$. The total mood disturbance score was significantly lower after walking in a forest area than after walking in a city area (forest: $0.1 \pm 4.9$; city: $7.7 \pm 7.3 ; p<0.01$ ).

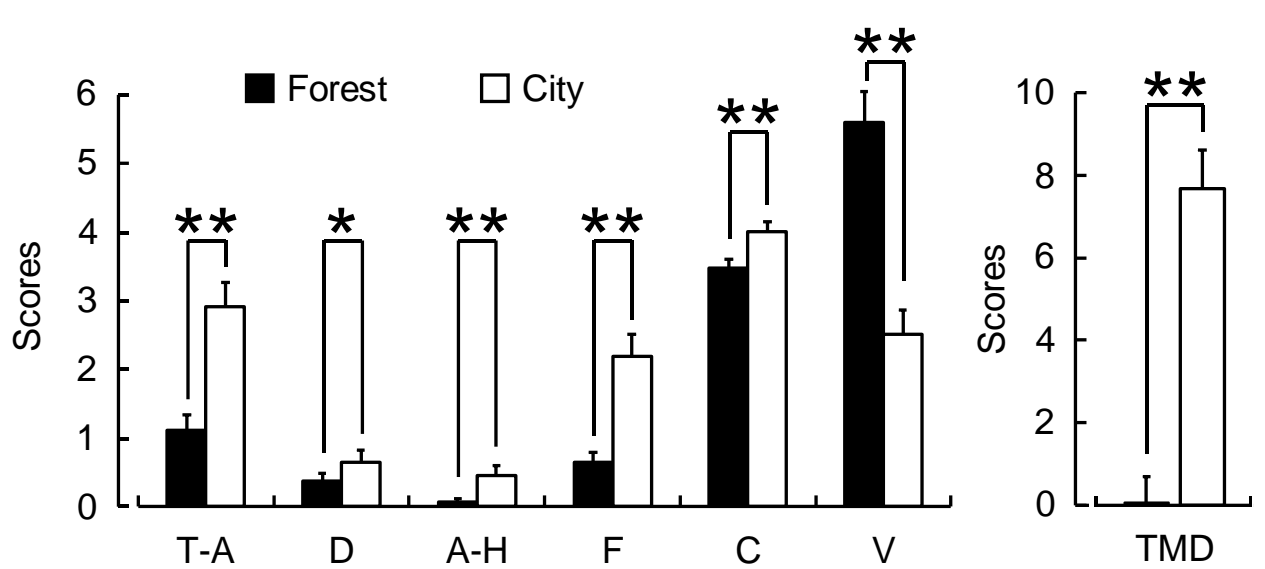

Figure 6. Subjective feelings as measured by the six subscales and the total mood disturbance (TMD) score of the Profile of Mood States questionnaire after walking through forest and city areas. Data are shown as means \pm standard deviation $(\mathrm{n}=60)$. ${ }^{* *} p<0.01,{ }^{*} p<0.05$, Wilcoxon signed-rank test (one-sided). T-A, tension and anxiety; D, depression and dejection; $\mathrm{A}-\mathrm{H}$, anger and hostility; $\mathrm{F}$, fatigue; C, confusion; V, vigor. 
Finally, the state anxiety score of the STAI was $34.8 \pm 7.2$ after walking in a forest area, significantly lower than $45.3 \pm 7.1$ after walking in a city area $(p<0.01$; Figure 7$)$.

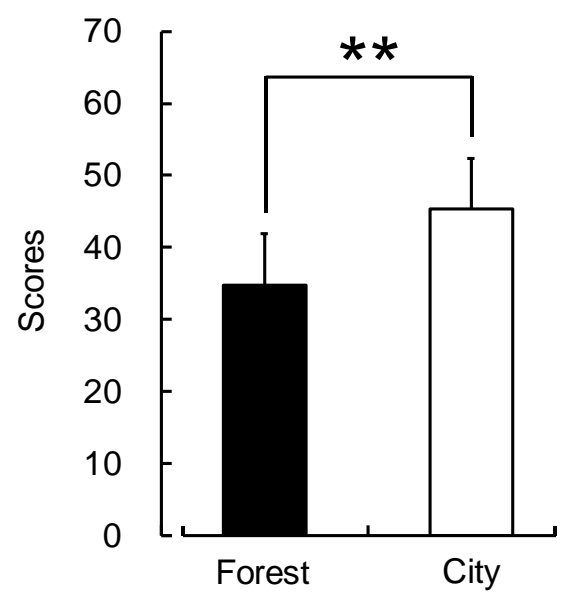

Figure 7. Subjective feelings after walking through forest and city areas as measured by the state anxiety score of the State-Trait Anxiety Inventory questionnaire. Data are expressed as means \pm standard deviation $(\mathrm{n}=60) .{ }^{* *} p<0.01$, Wilcoxon signed-rank test (one-sided).

\section{Discussion}

The present study assessed the physiological and psychological effects on young women of a brief walk through a forest.

Compared with walking in a city environment, a brief walk in a forest environment significantly increased the participants' parasympathetic nervous activity while reducing their sympathetic nervous activity and heart rate. This was consistent with findings of previous studies that investigated physiological responses to a forest environment in men $[5,7,9-13,16,17,19,25,28]$. The increase in parasympathetic nervous activity and suppression of sympathetic nervous activity suggested that a brief walk in a forest induces physiological relaxation.

However, there were no significant differences between the forest and city environments in the changes in the participants' blood pressure. The mean SBP value before walking was $95.6 \pm 1.2 \mathrm{mmHg}$ in the forest area and $95.9 \pm 1.3$ in the city area, and DBP was $58.6 \pm 1.0 \mathrm{mmHg}$ in the forest area and $58.8 \pm 1.0$ in the city area. Blood pressure in the range $120-129 / 80-85 \mathrm{mmHg}$ is widely regarded as normal, with $<120 / 80 \mathrm{mmHg}$ often cited as the optimal blood pressure [45], although this remains controversial. The mean blood pressures in this study seem to be very low, which meant it was necessary to raise the blood pressure closer to an appropriate level. A previous study found that participants with initially high blood pressure showed a decrease in blood pressure after walking in a forest, whereas those with initially low blood pressure showed an increase, suggesting that a forest environment can be used to help achieve an appropriate blood pressure [46]. From now on, it seems necessary to examine this point.

The psychological evaluations were generally in accordance with the physiological responses. Scores for the comfortable, relaxed, and natural parameters as well as the vigor subscale of the POMS were significantly higher after walking in a forest than after walking in a city area, whereas the scores for the negative feeling subscales, including tension-anxiety, depression-dejection, anger-hostility, fatigue, and confusion, were significantly lower, as was the total mood disturbance score and the STAI anxiety dimension score. These results, which demonstrate the psychological benefits of forests, are partly consistent with previous findings of the effects of viewing forest scenery or walking in forests on men $[9,11,47,48]$. Recent research has shown that city dwellers are constantly exposed to stressors and that urban living is associated with an increased risk of health problems [49-52]. In particular, mental health problems can be profound. Current city dwellers have a 39\% higher risk for mood 
disorders and a 21\% higher risk for anxiety disorders than those living in rural areas [50], and they have higher rates of psychotropic medication prescriptions for anxiety, depression, and psychosis [52]. Therefore, the psychological benefits of walking through forests could be clinically significant, and it is expected that forest environments will play very important roles in promoting mental health in the future.

The results of this study provide evidence that walking in a forest environment induces physiological and psychological relaxation in young women. However, the study had several limitations. First, the participants were limited to healthy female university students in their $20 \mathrm{~s}$. To generalize the findings, further studies are needed that include other demographic groups, including individuals of different ages. Second, the only physiological indices used were for autonomic nervous activity. For a more complete picture, a comprehensive examination using multiple indices, such as brain and endocrine activity, is necessary. These limitations should be considered in future research.

\section{Conclusions}

Our study revealed the following noteworthy findings regarding the effects of walking in a forest on young women: (1) higher parasympathetic nervous activity; (2) lower sympathetic nervous activity; (3) lower heart rate; (4) feeling more "comfortable", "relaxed", and "natural", as assessed by the modified SD method; (5) more improvement in the mood state, as assessed by the POMS; and (6) lower the anxiety level than those caused by walking in the city area. In conclusion, brief walks in forests induced physiological and psychological relaxation in healthy young women.

Author Contributions: C.S. performed data acquisition, statistical analysis, interpretation of the results, and manuscript preparation. H.I. was involved in data acquisition, statistical analysis, and interpretation of the results. T.K. designed the study and was involved in data acquisition. Y.M. had an important role in the overall performance of this research, particularly in experimental design, data acquisition, and manuscript preparation. All authors contributed to the preparation and are responsible for the final editing and approval of the manuscript.

Funding: This research received no external funding.

Acknowledgments: We appreciate Yuko Tsunetsugu of the University of Tokyo for support during the data collection phase of this study.

Conflicts of Interest: The authors declare no conflict of interest.

\section{References}

1. Selhub, E.M.; Logan, A.C. Your Brain on Nature: The Science of Nature's Influence on Your Health, Happiness and Vitality; Wiley: New York, NY, USA, 2012.

2. Miyazaki, Y. Shinrin Yoku: The Art of Japanese Forest Bathing; Octopus Publishing Group: London, UK, 2018; p. 192.

3. Song, C.; Ikei, H.; Miyazaki, Y. Physiological effects of nature therapy: A review of the research in Japan. Int. J. Environ. Res. Public Health 2016, 13, 781. [CrossRef] [PubMed]

4. Miyazaki, Y.; Motohashi, Y. Forest environment and physiological response. In New Frontiers in Health Resort Medicine; Agishi, Y., Ohtsuka, Y., Eds.; Hokkaido School of Medicine Press: Sapporo, Japan, 1996; pp. 67-77.

5. Tsunetsugu, Y.; Park, B.J.; Ishii, H.; Hirano, H.; Kagawa, T.; Miyazaki, Y. Physiological effects of Shinrin-Yoku (taking in the atmosphere of the forest) in an oldgrowth broadleaf forest in Yamagata Prefecture, Japan. J. Physiol. Anthropol. 2007, 26, 135-142. [CrossRef] [PubMed]

6. Park, B.J.; Tsunetsugu, Y.; Kasetani, T.; Hirano, H.; Kagawa, T.; Sato, M.; Miyazaki, Y. Physiological effects of Shinrin-Yoku (taking in the atmosphere of the forest)-using salivary cortisol and cerebral activity as indicators. J. Physiol. Anthropol. 2007, 26, 123-128. [CrossRef] [PubMed]

7. Park, B.J.; Tsunetsugu, Y.; Ishii, H.; Furuhashi, S.; Hirano, H.; Kagawa, T.; Miyazaki, Y. Physiological effects of Shinrin-yoku (taking in the atmosphere of the forest) in a mixed forest in Shinano Town, Japan. Scand. J. For. Res. 2008, 23, 278-283. [CrossRef]

8. Lee, J.; Park, B.J.; Tsunetsugu, Y.; Kagawa, T.; Miyazaki, Y. Restorative effects of viewing real forest landscapes, based on a comparison with urban landscapes. Scand. J. For. Res. 2009, 24, 227-234. [CrossRef] 
9. Park, B.J.; Tsunetsugu, Y.; Kasetani, T.; Kagawa, T.; Miyazaki, Y. The physiological effects of Shinrin-yoku (taking in the forest atmosphere or forest bathing): Evidence from field experiments in 24 forests across Japan. Environ. Health Prev. Med. 2010, 15, 18-26. [CrossRef]

10. Lee, J.; Park, B.J.; Tsunetsugu, Y.; Ohira, T.; Kagawa, T.; Miyazaki, Y. Effect of forest bathing on physiological and psychological responses in young Japanese male subjects. Public Health 2011, 125, 93-100. [CrossRef]

11. Tsunetsugu, Y.; Lee, J.; Park, B.J.; Tyrväinen, L.; Kagawa, T.; Miyazaki, Y. Physiological and psychological effects of viewing urban forest landscapes assessed by multiple measurements. Landsc. Urban Plan. 2013, 113, 90-93. [CrossRef]

12. Park, B.J.; Tsunetsugu, Y.; Kasetani, T.; Morikawa, T.; Kagawa, T.; Miyazaki, Y. Physiological effects of forest recreation in a young conifer forest in Hinokage Town, Japan. Silva Fenn. 2009, 43, 291-301. [CrossRef]

13. Lee, J.; Tsunetsugu, Y.; Takayama, N.; Park, B.J.; Li, Q.; Song, C.; Komatsu, M.; Ikei, H.; Tyrväinen, L.; Kagawa, T.; et al. Influence of forest therapy on cardiovascular relaxation in young adults. Evid. Based Complement. Alternat. Med. 2014, 2014, 834360. [CrossRef]

14. Li, Q.; Morimoto, K.; Nakadai, A.; Inagaki, H.; Katsumata, M.; Shimizu, T.; Hirata, Y.; Hirata, K.; Suzuki, H.; Miyazaki, Y.; et al. Forest bathing enhances human natural killer activity and expression of anti-cancer proteins. Int. J. Immunopathol. Pharmacol. 2007, 20, 3-8. [CrossRef] [PubMed]

15. Li, Q.; Morimoto, K.; Kobayashi, M.; Inagaki, H.; Katsumata, M.; Hirata, Y.; Hirata, K.; Suzuki, H.; Li, Y.J.; Wakayama, Y.; et al. Visiting a forest, but not a city, increases human natural killer activity and expression of anti-cancer proteins. Int. J. Immunopathol. Pharmacol. 2008, 21, 117-127. [CrossRef] [PubMed]

16. Park, B.J.; Tsunetsugu, Y.; Lee, J.; Kagawa, T.; Miyazaki, Y. Effect of the forest environment on physiological relaxation-the results of field tests at 35 sites throughout Japan. In Forest Medicine; Li, Q., Ed.; Nova Science Publishers, Inc.: New York, NY, USA, 2012; pp. 55-65.

17. Kobayashi, H.; Song, C.; Ikei, H.; Kagawa, T.; Miyazaki, Y. Analysis of individual variations in autonomic responses to urban and forest environments. Evid. Based Complement. Alternat. Med. 2015, 2015, 671094. [CrossRef] [PubMed]

18. Kobayashi, H.; Song, C.; Ikei, H.; Park, B.J.; Lee, J.; Kagawa, T.; Miyazaki, Y. Population-based study on the effect of a forest environment on salivary cortisol concentration. Int. J. Environ. Res. Public Health 2017, 14, 931. [CrossRef] [PubMed]

19. Kobayashi, H.; Song, C.; Ikei, H.; Park, B.J.; Lee, J.; Kagawa, T.; Miyazaki, Y. Forest walking affects autonomic nervous activity: A population-based study. Front. Public Health 2018, 6, 278. [CrossRef]

20. Ohtsuka, Y.; Yabunaka, N.; Takayama, S. Shinrin-Yoku (forest-air bathing and walking) effectively decreases blood glucose levels in diabetic patients. Int. J. Biometeorol. 1998, 41, 125-127. [CrossRef]

21. Mao, G.X.; Cao, Y.B.; Lan, X.G.; He, Z.H.; Chen, Z.M.; Wang, Y.Z.; Hu, X.L.; Lv, Y.D.; Wang, G.F.; Yan, J. Therapeutic effect of forest bathing on human hypertension in the elderly. J. Cardiol. 2012, 60, 495-502. [CrossRef]

22. Sung, J.; Woo, J.M.; Kim, W.; Lim, S.K.; Chung, E.J. The effect of cognitive behavior therapy-based "forest therapy" program on blood pressure, salivary cortisol level, and quality of life in elderly hypertensive patients. Clin. Exp. Hypertens. 2012, 34, 1-7. [CrossRef]

23. Lee, J.Y.; Lee, D.C. Cardiac and pulmonary benefits of forest walking versus city walking in elderly women: A randomised, controlled, open-label trial. Eur. J. Integr. Med. 2014, 6, 5-11. [CrossRef]

24. Ochiai, H.; Ikei, H.; Song, C.; Kobayashi, M.; Takamatsu, A.; Miura, T.; Kagawa, T.; Li, Q.; Kumeda, S.; Imai, M.; et al. Physiological and psychological effects of forest therapy on middle-aged males with high-normal blood pressure. Int. J. Environ. Res. Public Health 2015, 12, 2532-2542. [CrossRef]

25. Song, C.; Ikei, H.; Kobayashi, M.; Miura, T.; Taue, M.; Kagawa, T.; Li, Q.; Kumeda, S.; Imai, M.; Miyazaki, Y. Effect of forest walking on autonomic nervous system activity in middle-aged hypertensive individuals: A pilot study. Int. J. Environ. Res. Public Health 2015, 12, 2687-2699. [CrossRef] [PubMed]

26. Lee, I.; Choi, H.; Bang, K.S.; Kim, S.; Song, M.; Lee, B. Effect of forest therapy on depressive symptoms among adults: A systematic review. Int. J. Environ. Res. Public Health 2017, 14, 321. [CrossRef] [PubMed]

27. Chun, M.H.; Chang, M.C.; Lee, S.J. The effects of forest therapy on depression and anxiety in patients with chronic stroke. Int. J. Neurosci. 2017, 127, 199-203. [CrossRef] [PubMed]

28. Song, C.; Ikei, H.; Kobayashi, M.; Miura, T.; Li, Q.; Kagawa, T.; Kumedae, S.; Imaif, M.; Miyazakia, Y. Effect of viewing forest landscape on middle-aged hypertensive men. Urban For. Urban Green. 2017, 21, $247-252$. [CrossRef] 
29. Ochiai, H.; Ikei, H.; Song, C.; Kobayashi, M.; Miura, T.; Kagawa, T.; Li, Q.; Kumeda, S.; Imai, M.; Miyazaki, Y. Physiological and psychological effects of a forest therapy program on middle-aged females. Int. J. Environ. Res. Public Health 2015, 12, 15222-15232. [CrossRef]

30. Li, Q.; Morimoto, K.; Kobayashi, M.; Inagaki, H.; Katsumata, M.; Hirata, Y.; Hirata, K.; Shimizu, T.; Li, Y.J.; Wakayama, Y.; et al. A forest bathing trip increases human natural killer activity and expression of anti-cancer proteins in female subjects. J. Biol. Regul. Homeost. Agents 2008, 22, 45-55. [PubMed]

31. Kim, B.J.; Jeong, H.; Park, S.; Lee, S. Forest adjuvant anti-cancer therapy to enhance natural cytotoxicity in urban women with breast cancer: A preliminary prospective interventional study. Eur. J. Integr. Med. 2015, 7, 474-478. [CrossRef]

32. Camm, A.J.; Malik, M.; Bigger, J.T.; Breithardt, G.; Cerutti, S.; Cohen, R.J.; Coumel, P.; Fallen, E.L.; Kennedy, H.L.; Kleiger, R.E.; et al. Heart rate variability standards of measurement, physiological interpretation, and clinical use. Circulation 1996, 93, 1043-1065.

33. Kobayashi, H.; Ishibashi, K.; Noguchi, H. Heart rate variability; an index for monitoring and analyzing human autonomic activities. Appl. Hum. Sci. 1999, 18, 53-59. [CrossRef]

34. Kanaya, N.; Hirata, N.; Kurosawa, S.; Nakayama, M.; Namiki, A. Differential effects of propofol and sevoflurane on heart rate variability. Anesthesiology 2003, 98, 34-40. [CrossRef]

35. Sawada, Y.; Ohtomo, N.; Tanaka, Y.; Tanaka, G.; Yamakoshi, K.; Terachi, S.; Shimamoto, K.; Nakagawa, M.; Satoh, S.; Kuroda, S.; et al. New technique for time series analysis combining the maximum entropy method and non-linear least squares method: Its value in heart rate variability analysis. Med. Biol. Eng. Comput. 1997, 35, 318-322. [CrossRef]

36. Task Force of the European Society of Cardiology and the North American Society of Pacing and Electrophysiology. Heart rate variability: Standards of measurement, physiological interpretation and clinical use. Circulation 1996, 93, 1043-1065. [CrossRef]

37. Pagani, M.; Lombardi, F.; Guzzetti, S.; Rimoldi, O.; Furlan, R.; Pizzinelli, P.; Sandrone, G.; Malfatto, G.; Dell'Orto, S.; Piccaluga, E. Power spectral analysis of heart rate and arterial pressure variabilities as a marker of sympath o-vagal interaction in man and conscious dog. Circ. Res. 1986, 59, 178-193. [CrossRef] [PubMed]

38. Kobayashi, H.; Park, B.J.; Miyazaki, Y. Normative references of heart rate variability and salivary alpha-amylase in a healthy young male population. J. Physiol. Anthropol. 2012, 31, 9. [CrossRef] [PubMed]

39. Osgood, C.E.; Suci, G.J.; Tannenbaum, P. The Measurement of Meaning; University of Illinois Press: Urbana, IL, USA, 1957.

40. Mcnair, D.M.; Lorr, M. An analysis of mood in neurotics. J. Abnorm. Psychol. 1964, 69, 620-627. [CrossRef]

41. McNair, D.M.; Lorr, M.; Droppleman, L.F. Profile of Mood States Manual; Educational and Industrial Testing Services: San Diego, CA, USA, 1992.

42. Yokoyama, K. POMS Shortened Version-Manual and Commentary on Cases; Kaneko Syoboh: Tokyo, Japan, 2005. (In Japanese)

43. Spielberger, C.D.; Gorsuch, R.L.; Lushene, R.E. Manual for the State-Trait Anxiety Inventory; Consulting Psychologists Press: Palo Alto, CA, USA, 1970.

44. Julian, L.J. Measures of anxiety. Arthrit. Care Res. 2011, 63, 467-472. [CrossRef] [PubMed]

45. Shimamoto, K.; Ando, K.; Fujita, T.; Hasebe, N.; Higaki, J.; Horiuchi, M.; Imai, Y.; Imaizumi, T.; Ishimitsu, T.; Ito, M.; et al. The Japanese Society of Hypertension guidelines for the management of hypertension (JSH 2014). Hypertens. Res. 2014, 37, 253-390.

46. Song, C.; Ikei, H.; Miyazaki, Y. Elucidation of a physiological adjustment effect in a forest environment: A pilot study. Int. J. Environ. Res. Public Health 2015, 12, 4247-4255. [CrossRef]

47. Morita, E.; Fukuda, S.; Nagano, J.; Hamajima, N.; Yamamoto, H.; Iwai, Y.; Nakashima, T.; Ohira, H.; Shirakawa, T. Psychological effects of forest environments on healthy adults: Shinrin-Yoku (forest-air bathing, walking) as a possible method of stress reduction. Public Health 2007, 121, 54-63. [CrossRef]

48. Park, B.J.; Furuya, K.; Kasetani, T.; Takayama, N.; Kagawa, T.; Miyazaki, Y. Relationship between psychological responses and physical environments in forest settings. Landsc. Urban Plan. 2011, 102, 24-32. [CrossRef]

49. Tanaka, A.; Takano, T.; Nakamura, K.; Takeuchi, S. Health levels influenced by urban residential conditions in a megacity-Tokyo. Urban Stud. 1996, 33, 879-894. [CrossRef]

50. Peen, J.; Schoevers, R.A.; Beekman, A.T.; Dekker, J. The current status of urban-rural differences in psychiatric disorders. Acta Psychiatr. Scand. 2010, 121, 84-93. [CrossRef] [PubMed] 
51. Lederbogen, F.; Kirsch, P.; Haddad, L.; Streit, F.; Tost, H.; Schuch, P.; Wüst, S.; Pruessner, J.C.; Rietschel, M.; Deuschle, M.; et al. City living and urban upbringing affect neural social stress processing in humans. Nature 2011, 474, 498-501. [CrossRef]

52. McKenzie, K.; Murray, A.L.; Booth, T. Do urban environments increase the risk of anxiety, depression and psychosis? An epidemiological study. J. Affect. Disord. 2013, 150, 1019-1024. [CrossRef] [PubMed] 